\title{
Parohia - comunitate liturgică în lumea modernă
}

Svetomir MILICICI*

Abstract: The parish has a very important role in preaching the Gospel. The Saint Liturgy is the center of every believers life from a parish. The importance of laypersons in the life of parish comunity. The article analyses a few priorities for the improvement of the church mission in the modern world, in which we live.

Keywords: parish, modernism, priority, obligations.

\section{Preliminarii}

Parohia este, potrivit Art. 43 al Statutului pentru organizarea şi funcţionarea Bisericii Ortodoxe Române, comunitatea credincioşilor ortodocşi, clerici şi mireni, situată pe un anume teritoriu şi subordonată centrului eparhial din punct de vedere canonic, juridic, administrativ

\footnotetext{
* PhD Candidate, Faculty of Orthodox Theology at "Aurel Vlaicu" University in Arad, Romania.
} 
şi patrimonial, condusă de un preot paroh numit de chiriarhul (arhiepiscopul sau episcopul) eparhiei respective².

Preotul paroh, ca delegat al chiriarhului, potrivit Art. 49 al Statutului pentru organizarea şi funcţionarea Bisericii Ortodoxe Române, este păstorul sufletesc al credincioşilor dintr-o parohie, iar în activitatea administrativă este conducătorul administraţiei parohiale şi preşedinte al Adunării parohiale, al Consiliului parohial şi al Comitetului parohial ${ }^{3}$. Potrivit învăţăturii bisericeşti, el este părintele duhovnicesc, învăţătorul turmei încredinţate, precum şi săvârşitorul rânduielilor liturgice stabilite de Biserică. Astfel, preotul este parte a succesiunii apostolice prin hirotonia de către episcop şi deține această întreită slujire: preoţească, învăţătorească şi sfinţitoare. El este dator să predice cu regularitate Cuvântul lui Dumnezeu şi să îi înveţe pe enoriaşii săi în Biserică şi în fiecare alt loc prielnic.

Sfânta Liturghie este centrul vieţii fiecărui credincios dintr-o parohie, în această lume modernă, secularizată, având ca punct culminant unirea cu Hristos prin împărtăşirea cu Sfintele Taine. Însă împărtăşirea cu Trupul şi Sângele Domnului nu este doar plinirea ostenelilor şi ţinta spre care năzuim, ci este şi ajutorul divin pe care îl primim în nevoinţa noastră duhovnicească şi care ne ajută să aspirăm către o comuniune desăvârşită, în ziua cea neînserată a Împărăţiei lui Dumnezeu. Euharistia, ca centru al cultului creştin, este un mod de mijlocire între Dumnezeu şi om, căci atunci când harul Sfântului Duh se pogoară asupra darurilor, acestea se prefac în Însuşi Hristos, ritualul întregii slujbe simbolizând întreaga viaţă lui Hristos ${ }^{4}$ Putem spune, cu alte cuvinte, că parohia este o comunitate liturgică, în centrul căreia este Hristos Domnul prezent real, căci ,unde sunt doi sau trei adunaţi în numele Meu, acolo sunt şi Eu în mijlocul lor" (Matei 18:20). Noi

\footnotetext{
${ }^{2} \mathrm{http}: / /$ patriarhia.ro/images/documente/statutul_bor.pdf (accesat iunie 8, 2015). ${ }^{3} \mathrm{http}$ //patriarhia.ro/images/documente/statutul_bor.pdf (accesat iunie 8, 2015) ${ }^{4}$ Pr. Prof. Dr. C., N. Buzescu, Liturghia-centrul cultului ortodox, în „Ortodoxia”, an 1981, nr. 1, p. 41-57.
} 
suntem părtaşi acum la Împărăţia lui Dumnezeu care va să vină. Vedem şi pregustăm slava şi binecuvântarea ei, dar suntem încă pe pământ şi întreaga noastră existenţă pământească este astfel o lungă şi adesea dureroasă călătorie către Ziua Domnului .

„Participarea la Sfânta Liturghie de duminică şi din sărbători este pentru membrii parohiei manifestarea conştientă a legăturii lor nemijlocite cu Hristos, dar şi a unităţii lor în Hristos, unii cu alţii. Slujirea liturgică aparține fiecăruia dintre cei care participă, împreună cu preotul lor, la săvârşirea Sfintelor Taine, la aducerea jertfei de rugăciune şi la primirea darurilor duhovniceşti revărsate de Dumnezeu asupra Bisericii, închinându-se pe ei înşişi şi unii pe alţii lui Dumnezeu, membrii parohiei sunt părtaşi, în fiecare slujbă, lucrării mântuitoare a lui Hristos, iar prin împărtăşirea cu Trupul şi Sângele Domnului primesc, în jertfa unică a Mântuitorului, izbăvirea de păcat şi sămânţa învierii şi vieţii veşnice în trupurile lor"6.

Dragostea lui Dumnezeu pentru noi nu este de natură psihologică sau raţională ci personală, în persoana lui Iisus Hristos. De aceea spune apostolul Ioan: „Întru aceasta s-a arătat dragostea lui Dumnezeu către noi, că pe Fiul Său cel Unul Născut L-a trimis Dumnezeu în lume, ca prin El viaţă să avem" (I Ioan 4:9). Şi această cunoaştere a lui Dumnezeu, prin dragostea lui Hristos, constituie Biserica şi de aceea noi Îl cunoaştem pe Dumnezeu numai în Biserică, în Hristos. Cunoaşterea lui Dumnezeu presupune intrarea în Biserică (prin botez), în comunitate unde iubind unii pe alţii, Îl iubim pe Însuşi Dumnezeu pentru că Dumnezeu este iubire?

Parohia, prin membri Comitetului de Conducere, reprezintă şi apără interesele comunităţii bisericeşti, ajutând preotul să apere şi să

\footnotetext{
${ }^{5}$ Alexander Schmemann, Euharistia Taina Împărăţiei, Bucureşti, Editura Bonifaciu, 2003, p. 136.

6 http://www.crestinortodox.ro/drept-bisericesc/parohia-comunitate-liturgicamisionara-69916.html (accesat iunie 10, 2015).

${ }^{7}$ Episcopul Ignjatije Midici, Secanje na buducnost, Belgrad, Tipografia Novi dani, 1995 p. 62-63).
} 
menţină în rândul enoriaşilor credinţa ortodoxă, luptând împotriva oricărei lucrări potrivnice şi dăunătoare învăţăturii ortodoxe. Ea are un rol foarte important atât în propovăduirea Evangheliei cât şi în transmiterea tradiţiilor şi obiceiurilor locale generaţiilor viitoare.

Lucrarea Bisericii în societatea de astăzi trebuie să fie responsabilă, să fie spre mântuire, preotul să fie mereu acela care-i apropie pe oameni de biserică, de Liturghie, de Domnul nostru Iisus Hristos. Aceasta ar fi misiunea lui de bază într-o parohie, dar de multe ori se impun şi alte obligaţii care ţin mai mult de domeniul asistenţei sociale. Totuşi asistenţa socială presupune, din partea celui care o practică, o serie de calităţi personale, aptitudini deosebite, care prin educaţie dezvoltă deprinderi şi abilităţi, formează talentul necesar pentru a acţiona într-o mare diversitate de situaţii, pentru a-i putea înţelege pe oameni şi a-i ajuta pe ei să se ajute singuri.

Aş analiza câteva priorităţi care ar duce la îmbunătăţirea misiunii Bisericii în lumea modernă în care trăim. Fiind preot în diaspora (Episcopia Ortodoxă Sârbă, Ungaria), am observat că este foarte important, în primul rând, cum ne raportăm la celelalte culte şi confesiuni, alături de care convieţuim. Chiar în componenţa parohiei şi a filiilor care îmi sunt încredinţate spre păstorire, se află multe familii mixte, aşa că misiunea devine uneori grea şi trebuie făcută cu multă atenţie şi acurateţe. Foarte logic şi deosebit de pregnant a definit relaţiile Bisericii Ortodoxe cu celelalte culte răposatul întru fericiţi dr. Danilo Krstici' ${ }^{8}$, episcopul Budei, indicând trei nivele de

8Dr. Danilo Krstici, episcopul Budei, a fost unul din cei mai de seamă ierarhi ai Bisericii Ortodoxe Sârbe şi bine cunoscut în întreaga lume ortodoxă. S-a născut la 13 mai 1927 în Novi Sad (Serbia), unde a terminat şcoala primară şi liceul. În anul 1946 a urmat, timp de un an, Facultatea de Drept de la Universitatea din Belgrad. Un an mai târziu s-a înscris la Universitatea din Sorbona (Paris), la studii de literatură comparată. După absolvire, studiază un an ştiinţele tehnice la Munchen, iar in anul 1958 revine la Paris şi se înscrie la Institutul Teologic Ortodox Sfântul Serghie. După absolvire, în luna septembrie a anului 1958, îndrumat de cunoscutul profesor pr. Georges Florovsky, a început să lucreze la 
coexistenţă, de colaborare.

Primul nivel este cel material, zilnic, de întâlnire, de producţie, de cumpărare şi vânzare, de lucrări întreprinse în comun. La acest nivel pot exista înţelegeri, colaborări, iniţiative. Este nivelul cel mai frecvent, dar cel mai scăzut sub aspect duhovnicesc.

Al doilea nivel este cel cultural, aici incluzându-se şi ştiinţa. Se poate discuta despre stiluri de arhitectură, se pot dezbate teme literare, teme etice, se pot face în comun experimente şi descoperiri ştiinţifice, folosindu-se aceeaşi utilare de laborator etc.

Nivelul al treilea este cel al credinţei, al învăţăturii, al dogmelor şi canoanelor; acolo problemele se pun în modul cel mai acut, intransigent şi nu este loc de nici o concesie, oricât de ademenitoare pot fi scopurile proclamate. În măsură în care învăţătura de credinţă a conlocutorului este depărtată de cea a ortodoxului, la acel nivel nu se

teza de doctorat, Sfântul Ioan Gură de Aur ca un teolog al filantropiei divine, la Facultatea de Teologie de la Universitatea Harvard. În anul 1968 devine doctor în teologie. Cu binecuvântarea Patriarhului sârb German este tuns în monahism la mănăstirea Sfântul Sava din Libertyville (Chicago), hirotonit ierodiacon la aceeaşi mănastire şi ieromonah la biserica Sfântul Sava din New York. După ce se întoarce în Serbia, în anul 1968, este numit redactor la ziarul oficial al Bisericii Ortodoxe Sârbe „Glasnik“(Monitorul) şi al revistei „Teološki pogledi“ (Opinii teologice), care revistă a avut la acea vreme cea mai de seamă reputaţie de specialitate în lume. În anul 1969 este ales Episcop de Marča, Episcop vicar al Patriarhului Sârb German. Din anul 1984 devine administrator al Episcopiei de Buda, din anul 1988 Episcop de Buda cu sediul la Budapesta şi în anul 1990 este întronizat la Szentendre (lângă Budapesta), actualul sediu al Episcopiei Sârbe din Ungaria. A păstorit această Episcopie până la moartea sa, la 20 aprilie 2002. A fost înmormântat la mănăstirea Vavedenje aproape de Belgrad. Episcopul dr. Danilo Krstić a predat Teologia Pastorală la Facultatea de Teologie a Bisericii Ortodoxe Sârbe între anii 1993 - 1997, fiind unul dintre fondatorii acesteia şi primul profesor şi decan al Academiei de Conservare din Belgrad, înfiinţată în anul 1993. Lucrările sale teologice şi literare sunt publicate în numeroase cărţi, reviste de specialitate, atât în Biserica Ortodoxă Sârbă cât şi în publicaţiile altor Biserici. 
poate colabora nici prin pogorământ 9 . Încercările de a se ocoli acest adevăr esenţial au dus la discuţii interminabile şi inutile.

La nivelele inferioare de comunicare, Biserica Ortodoxă este tolerantă faţă de toţi, abordabilă şi cooperantă; doar la nivelul dogmatic ea rămâne fermă şi nu poate avea comuniune decât cu marea familie ortodoxă, din care face parte.

O altă prioritate ar fi familia creştină, rolul şi importanţa ei într-o parohie. Am observat faptul că mulţi din cei care vor să încheie o căsătorie nu ştiu care sunt condiţ̧iile pe care trebuie să le îndeplinească pentru aceasta iar după încheierea căsătoriei, care sunt obligaţiile şi drepturile lor şi, mai précis, care este statutul lor în faţa lui Dumnezeu şi al oamenilor, adică în Biserică. Instituţia căsătoriei a făcut obiectul unei deosebite atenţii din partea tuturor legiuitorilor, încă din timpurile anterioare creştinismului; chiar statele necreştine au căutat întotdeauna să dea familiei o organizaţie cât mai potrivită, pentru ca în acest fel, să corespundă scopului şi rolului ei atât de însemnat ${ }^{10}$.

Nici o instituţie nu are un rol atât de hotărâtor pentru om şi societate ca familia, cu ea stând sau pierzându-şi binele particular şi cel public şi de ea atârnând, în mare măsură, ruina şi prosperitatea naţiunilor. Poate fi asemănată foarte bine cu o temelie şi este lucru cunoscut că, dacă la o casă temelia este puternică, clădirea stă neclintită, tot aşa, dacă într-o societate familia este aşezată pe idei sănătoase, întregul trup social progresează ${ }^{11}$.

A treia prioritate pentru îmbunătăţirea misiunii Bisericii în lumea modernă în care trăim ar fi o continuă catehizare, atât pentru cei tineri cât şi pentru cei adulţi, ferindu-i astfel pe credincioşi de orice ispită

\footnotetext{
${ }^{9}$ Dr. Danilo Krstici, episcopul Budei. Acestea le-am reţinut de la cursurile de Teologie Pastorală ţinute de Episcopul Danilo la Facultatea de Teologie a Bisericii Ortodoxe Sârbe din Belgrad, între anii 1993 - 1997.

${ }^{10}$ Pr. Dr. Gheorghe T. Soare, Impedimente la căsătorie şi motive de divorţ, în „Biserica Ortodoxă Română”, an LXI (1943), nr. 4-6, p. 230).

${ }^{11}$ Pr. Ştefan Slevoacă, Căsătoria creştină, în „Mitropolia Moldovei şi Sucevei”, an 1967 , nr. 9-10, p. 612).
} 
a acestei lumi moderne. Cei mai mari duşmani al zilelor noastre sunt secularizarea, consumismul, hedonismul şi indiferentismul religios. Societatea consumistă, după cum subliniază conf. dr. Cristinel Ioja, „se doreşte a fi un paradis, un nou paradis al desfătărilor, însă doar al desfătărilor trupului, pentru că sufletul şi-a pierdut valoarea sa nepreţuită, după cum şi omul şi-a pierdut credinţa în valoarea sa veşnică, într-o altă lume decât cea actuală. Într-o asemenea stare, fără conştiinţa prezenţei lui Dumnezeu în lume, bunăstarea lumii este însoţită de sărăcie, bogăţia de mizerie, fericirea de tristeţe, sănătatea de boală, iubirea de ură, bunătatea de egoism, liniştea de teamă, siguranţa de nesiguranţă"

În concluzie, subliniem că parohia este comunitatea de bază a Bisericii, liturgică şi spirituală, unde se exercită întreita slujire a lui Dumnezeu prin clerici şi dreptcredincioşi.

\section{Bibliografie}

1. Episcopul Ignjatije Midic, Secanje na buducnost, Belgrad, Tipografia Novi dani, 1995.

2. Ioja, Cristinel , Homo Economicus. Iisus Hristos, sensul creaţiei şi insuficienţele purului biologism, Timişoara, Editura Marineasa, an 2010.

3. Schmemann, Alexander, Euharistia Taina Împărăţiei, Bucureşti, Editura Bonifaciu, 2003.

4. Slevoacă, Ştefan, Căsătoria creştină, în „Mitropolia Moldovei şi Sucevei", an 1967.

5. Soare, T. Gheorghe, Impedimente la căsătorie şi motive de divorţ, în „Biserica Ortodoxă Română”, an LXI (1943), nr. 4-6.

\section{Surse web}

1. http://patriarhia.ro/images/documente/statutul_bor.pdf (accesat iunie 8, 2015).

2. http://www.crestinortodox.ro/drept-bisericesc/parohia-comunitateliturgica-misionara-69916.html (accesat iunie 10, 2015).

${ }^{12}$ Conf. Dr. Cristinel Ioja, Homo Economicus. Iisus Hristos, sensul creaţiei şi insuficienţele purului biologism., Timişoara, Editura Marineasa, an 2010, p. 288. 
